\title{
Developmentally Regulated Spontaneous Activity in the Embryonic Chick Retina
}

\author{
Wai T. Wong, Joshua R. Sanes, and Rachel O. L. Wong \\ Department of Anatomy and Neurobiology, Washington University School of Medicine, St. Louis, Missouri 63110
}

\begin{abstract}
Even before birth and the onset of sensory experience, neural activity plays an important role in shaping the vertebrate nervous system. In the embryonic chick visual system, activity in the retina before vision has been implicated in the refinement of retinotopic maps, the elimination of transient projections, and the survival of a full complement of neurons. In this study, we report the detection of a physiological substrate for these phenomena: waves of spontaneous activity in the ganglion cell layer of the embryonic chick retina. The activity is robust and highly patterned, taking the form of large amplitude, rhythmic, and wide-ranging waves of excitation that propagate across the retina. Activity waves are most prominent and organized between embryonic days 13-18, coinciding with the developmental period during which retinal axons refine their connections in
\end{abstract}

Connectivity in the visual system develops in two phases: the formation of organized but imprecise connections followed by the elimination of aberrant projections to generate precise connections (Roskies et al., 1995; Katz and Shatz, 1996). The latter process involves neuronal activity as an essential component, because pharmacological blockade of activity slows or prevents its completion (Constantine-Paton et al., 1990; Katz and Shatz, 1996). However, more than the presence of activity per se is needed; theoretical (Hebb, 1949; Wilshaw and von der Malsburg, 1976; Miller, 1996) and experimental (Stryker and Strickland, 1984; Weliky and Katz, 1997) findings suggest that specific patterns of activity may be necessary to convey the appropriate information to specify connectivity during development.

Many of the activity-dependent rearrangements in connectivity occur before eye-opening or even before photoreceptor maturation and therefore do not require visual input. Instead, the relevant activity may take the form of propagating waves of spontaneous action potentials that have been revealed in mammalian retina. These patterns have spatial and temporal properties that can potentially influence the fine tuning of connectivity between retinal ganglion cells and their subcortical targets (Meister et al., 1991; Wong et al., 1993, 1995; Feller et al., 1996; Wong and Oakley, 1996; for review, see Wong, 1997). However, it remains unclear whether such activity patterns occur and are used to specify connectivity in other vertebrates, what specific patterns

\footnotetext{
Received July 9, 1998; accepted Aug. 11, 1998.

This work is supported by Esther A. and Joseph Klingenstein and A. P. Sloan fellowships to R.O.L.W. and by a National Institutes of Health grant to J.R.S. We thank Dr. Karen Myhr for help with data management programs and Chris Lee for extracellular recordings.

Correspondence should be addressed to Dr. Rachel O. L. Wong, Department of Anatomy and Neurobiology, Washington University School of Medicine, 660 South Euclid, St. Louis, MO 63110.

Copyright (C) 1998 Society for Neuroscience $\quad 0270-6474 / 98 / 188839-14 \$ 05.00 / 0$
}

their targets. The spatial and temporal features of the patterns observed are consistent with the role of activity patterns in shaping eye-specific projections and retinotopic maps but inconsistent with the hypothesis that they specify lamina-specific projections in the tectum. Antagonists of glutamatergic and glycinergic transmission and of gap junctional communication suppress spontaneous activity, whereas antagonists to GABAergic transmission potentiate it. Based on these results, we propose that spontaneous activity in the ganglion cells is regulated by chemical inputs from both bipolar and amacrine cells and by gap junctional coupling involving ganglion cells.

Key words: synchronized activity; chick visual system; ganglion cells; correlated activity; retinal waves; bursting activity

of connections they can influence, and whether these specialized activity patterns are generated by a common mechanism in all developing retinae.

To address these issues, we have determined the pattern and properties of spontaneous activity in the embryonic chick retina. The development of the avian retinotectal projection has been characterized in detail (for review, see Mey and Thanos, 1992) and clearly includes activity-dependent steps. Although topographic at the outset, retinal projections to the tectum are initially diff use and bilateral. As development proceeds, aberrantly placed arbors and ipsilateral connections are eliminated to form a retinotopically precise and crossed (contralateral) projection. Suppressing either the generation or reception of retinal signals before hatching perturbs the refinement of the retinotopic maps (Kobayashi et al., 1990; Pequignot and Clarke, 1992b; Wu et al., 1996), inhibits the elimination of transient ipsilateral projections (Pequignot and Clarke, 1992a; Wu et al., 1994), and delays or reduces the extent of naturally occurring cell death in the eye and its targets in the brain (Pequignot and Clark, 1992a; Kobayashi, 1993). In addition, all retinal axons terminate in just three of 16 tectal laminae, and each individual axon confines its synapses to just one of these retinorecipient laminae (Angaut and Reperant, 1976; Acheson et al., 1980; Yamagata and Sanes, 1995b). Coordinated spontaneous activity in the chick retina might therefore provide a physiological substrate for establishing each of these connectivity patterns.

Using optical recording and electrophysiological techniques, we observed wave-like patterns of propagated spontaneous activity in the isolated embryonic chick retina. As in the ferret, these patterns are developmentally regulated and are most robust and organized during the period when activity-dependent rearrangements in connectivity are known to occur (Wong et al., 1993; Penn et al., 1998). Analysis of their spatial and temporal proper- 
ties suggests that patterns of spontaneous activity can underlie topographic mapping and ipsilateral elimination. In contrast, our analysis indicates that activity is unlikely to strongly influence laminar specificity in the tectum. In this way, the chick retinotectal system differs from the ferret retinogeniculate system in which activity patterns may specify ON versus OFF sublamination (Wong and Oakley, 1996). Finally, the effects of antagonists to neurotransmitter receptors and gap junctions indicate that spontaneous activity of ganglion cells in the chick, as in the ferret, is mediated by intercellular communication but is different in that it is dependent on excitatory glutamatergic drive and may involve gap junctional communication.

Parts of this paper have been published previously (Wong et al., 1997).

\section{MATERIALS AND METHODS}

Tissue preparation. Fertilized chicken eggs were purchased from SPAFAS (Roanoke, IL) and were incubated at $37.5^{\circ} \mathrm{C}$. Only embryos that were developing normally according to the Hamburger and Hamilton (1951) staging system were used. The embryos were decapitated and enucleated, and the eye cups were immersed in ice-cold, oxygenated Ringer's solution $\left(2 \mathrm{mM} \mathrm{CaCl}_{2}, 5 \mathrm{~mm} \mathrm{KCl}, 2 \mathrm{~mm} \mathrm{MgCl}, 124 \mathrm{~mm} \mathrm{NaCl}, 1.25 \mathrm{~mm}\right.$ $\mathrm{KH}_{2} \mathrm{PO}_{4}, 20 \mathrm{~mm}$ glucose, and $20 \mathrm{~mm}$ HEPES), and retinae were dissected into $4 \times 4 \mathrm{~mm}$ squares. Squares of retina were floated on a glass microscope slide and flipped scleral surface upward. Only retinal tissue from the peripheral half of the dorsal quadrant was used to minimize variability. A piece of black Millipore filter (HABP; Millipore, Bedford, MA) was touched to each retina and wetted with Ringer's solution, thereby attaching the retina to a solid support with the ganglion cell layer facing outward. The filter papers and adhering retinae were transferred to a beaker containing oxygenated Ringer's solution.

Physiological recordings. Retinae were incubated in an oxygenated solution containing $10 \mu \mathrm{M}$ fura- $2 \mathrm{AM}$ and $0.001 \%$ pluronic acid (Molecular Probes, Eugene, OR) in Ringer's medium, pH 7.4. After a $30 \mathrm{~min}$ incubation at room temperature, the temperature was raised to $30^{\circ} \mathrm{C}$ for another $30 \mathrm{~min}$. The retinae were then washed in Ringer's solution and transferred to a temperature-controlled recording chamber, through which oxygenated Ringer's solution was superfused.

The ganglion cell layer (GCL) was viewed using a low light level camera (SIT, Hamamatsu; Fryer Company, Huntley, IL), and images of the cells were acquired under computer control (Image 1-FL; Universal Imaging Corporation, West Chester, PA). Single-cell optical recordings were performed at high magnification using a $63 \times$ water-immersion objective with sequential excitation at 340 and $380 \mathrm{~nm}$ with a shutter and a Lambda-10 filter wheel (Sutter Instruments, Novato, CA). Each image was an average of 16 frames, and pairs of images were acquired every 2 sec and stored on an optical disk (Panasonic TQ3038; Fryer Company). An estimate of intracellular calcium levels $\left(\left[\mathrm{Ca}^{2+}\right]_{\mathrm{i}}\right)$ was generated from a calibration curve obtained from standard solutions as described by Wong and Oakley (1996). Recording of retinal fields at low magnification using a $2.5 \times$ objective was performed with excitation at $380 \mathrm{~nm}$ light. Images consisting of eight frame averages were captured every $1.4 \mathrm{sec}$. Image processing was performed using Metamorph (Universal Imaging Corporation).

In pharmacological studies, images were collected before and during superfusion of solutions containing various antagonists and again after washout of the antagonists. All solutions were prepared on the day of recording. Blockers used were a kainate/AMPA receptor antagonist, 1,2,3,4-tetrahydro-6-nitro-2,3-dioxo-benzo[f]quinoxaline-7-sulfonamide disodium (NBQX) (Research Biochemicals, Natick, MA); an NMDA receptor antagonist, (+)-2-amino-5-phosphonopentanoic acid (APV) (Research Biochemicals); a GABA $\mathrm{A}_{\mathrm{A}}$ receptor antagonist, (-)-bicuculline methbromide (Research Biochemicals); a glycine receptor blocker, strychnine hydrochloride (Sigma, St. Louis, MO); two nicotinic acetylcholine receptor antagonists, mecamylamine hydrochloride (Sigma) and hexamethonium bromide hydrate (Aldrich, Milwaukee, WI); three gap junctional blockers, $18 \alpha$-glycyrrhetinic acid, $18 \beta$-glycyrrhetinic acid, and carbenoxylone disodium salt (Sigma); and the chemically related, inactive compound glycyrrhizic acid.

Labeling of cells using green fluorescent protein. In one set of experiments, retinae mounted on filter paper were transfected with DNA coding for green fluorescent protein (GFP) (Life Technologies, Gaith- ersburg, MD; Clontech, Palo Alto, CA) using particle-mediated gene transfer. We used a hand-held biolistics device (Helios Gene Gun; Bio-Rad, Hercules, CA) to propel gold particles (Bio-Rad; diameter of particles $=1.0 \mu \mathrm{m}$; total gold per transfection $=25 \mathrm{mg}$ ) coated with DNA into the nuclei of GCL cells (transfection pressure $=40 \mathrm{psi}$ ). The resulting retinae were then incubated in an oxygenated chamber in Ringer's solution supplemented with 5\% fetal calf serum (Life Technologies). The transfected cells express GFP within $12 \mathrm{hr}$, revealing their dendritic and axonal morphology in fine detail. The retinae were then loaded with fura-2 AM dye and subjected to optical imaging using the protocol described above. Images of the GFP-labeled cells were collected by the use of an SIT camera or confocal microscopy (Fluoview; Olympus Optical, Tokyo, Japan).

Cross-correlation analysis. To perform a cross-correlation analysis of the bursting activity between two cells, we rasterized the plots of intracellular calcium concentration (described in detail in Wong and Oakley, 1996; Fischer et al., 1998). We first obtained the differential of the calcium plots using Igor (Wavemetrics); a threshold was then set for each cell above which the bursts were clearly represented by raster lines. These rasters were then subjected to cross-correlation analysis by obtaining the Spearman correlation matrices using Systat 5.2 (SPSS, Chicago, IL). The correlation coefficients for pairs of cells are plotted; a coefficient of 1.0 indicates perfect correlation in the bursting of the two cells, a coefficient of 0.0 indicates that the two cells burst independently, and a negative coefficient indicates that the activity of the two cells are anticorrelated.

Combined calcium imaging and extracellular recording. Extracellular recordings were performed while recording optically from fura-2-loaded chick retinal whole mounts. To perform the extracellular recordings, we filled glass micropipettes with Ringer's solution and beveled the pipettes to a final resistance of 6-8 M 2 . The signals were amplified using a Axopatch 200B amplifier, set at current clamp. The signals were filtered between 300 and $1000 \mathrm{~Hz}$ and stored on digital tape (DAT recorder; Sony, Tokyo, Japan). The data were then sampled off-line at $2 \mathrm{kHz}$ and plotted using a computer program written by C. W. Lee.

\section{RESULTS}

\section{Spontaneous activity in the ganglion cell layer}

We recorded the activity of cells in the GCL optically at high magnification, using the $\mathrm{Ca}^{2+}$-sensitive dye fura-2 AM. Cells imaged in this manner underwent large elevations of $\left[\mathrm{Ca}^{2+}\right]_{\mathrm{i}}$ that occurred at regular intervals over the entire length of the recording (up to $2 \mathrm{hr}$ ). Figure $1 A$ shows a typical field of fura-2-loaded GCL cells from an embryonic day 16 (E16) chick retina. Figure $1 B$ plots the $\left[\mathrm{Ca}^{2+}\right]_{\mathrm{i}}$ of three sampled cells within this field as a function of time. Rhythmic activity was prominent and robust in all the cells monitored and involved $\left[\mathrm{Ca}^{2+}\right]_{\mathrm{i}}$ elevations of $100-$ $300 \mathrm{~nm}$ above resting levels, with a rapid rising phase $(2-3 \mathrm{sec})$ and a more prolonged decay phase $(10-12 \mathrm{sec})$. As can be seen in Figure $1 B$, these elevations occurred simultaneously in different cells, and this synchrony observed between cells was maintained throughout the recording. The elevations were separated by comparatively longer periods of quiescence, the duration of which varied with temperature. Although large $\left[\mathrm{Ca}^{2+}\right]_{i}$ elevations were not detected below $24^{\circ} \mathrm{C}$, the interval between elevations decreased as a function of temperature from 24 to $34^{\circ} \mathrm{C}$ (data not shown). Subsequent recordings were performed at $34^{\circ} \mathrm{C}$.

To examine the relationship between the $\left[\mathrm{Ca}^{2+}\right]_{\mathrm{i}}$ elevations observed in a cell and its electrical activity, we performed extracellular recordings in our fura-labeled whole-mount preparations. An electrode was placed near a GCL cell that had been loaded with fura-2 AM, and spike activity was recorded simultaneously with calcium imaging. Figure $1 C$ shows the spontaneous activity of a single GCL cell as revealed by simultaneous extracellular recording and optical imaging. Each $\left[\mathrm{Ca}^{2+}\right]_{\mathrm{i}}$ elevation detected optically corresponded to a burst of action potentials, indicating that retinal ganglion cells (RGCs) are likely to convey these bursts to the tectum. Bursts of action potentials were typically 5-8 sec in duration. 
A

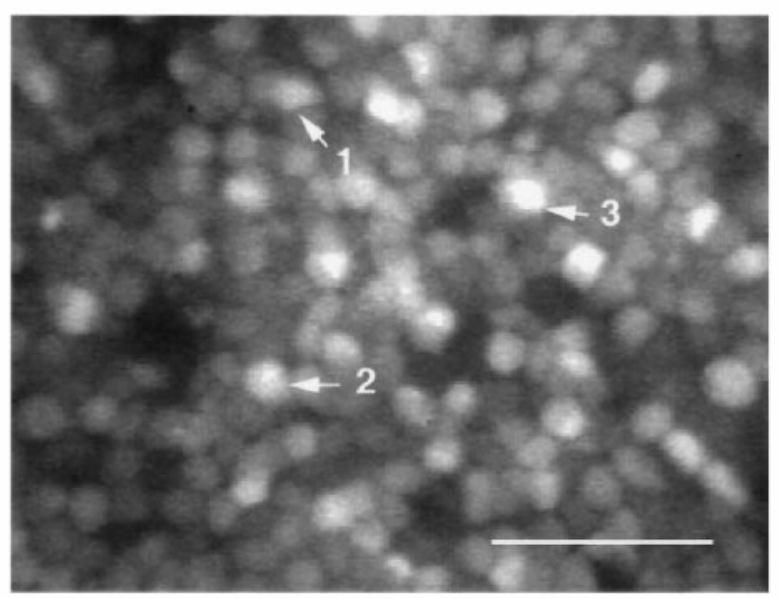

C
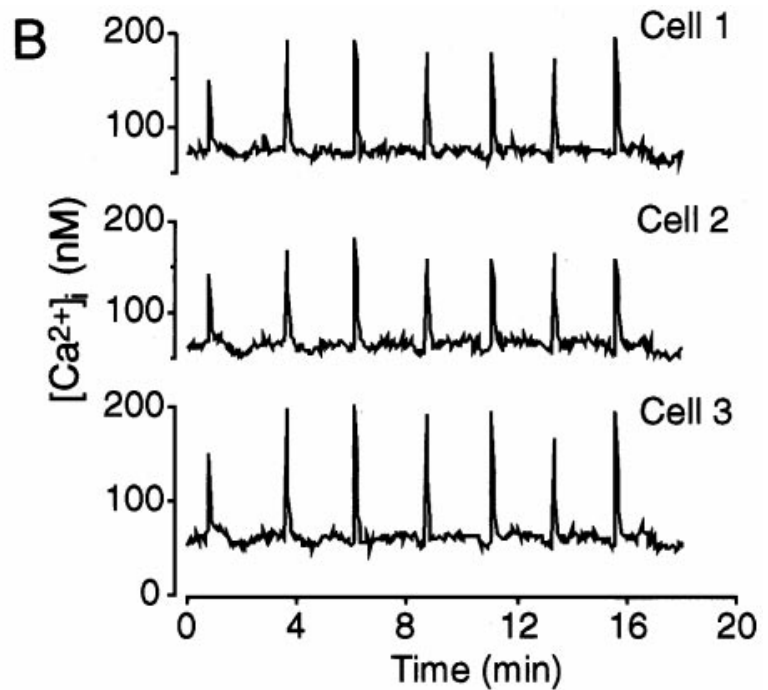

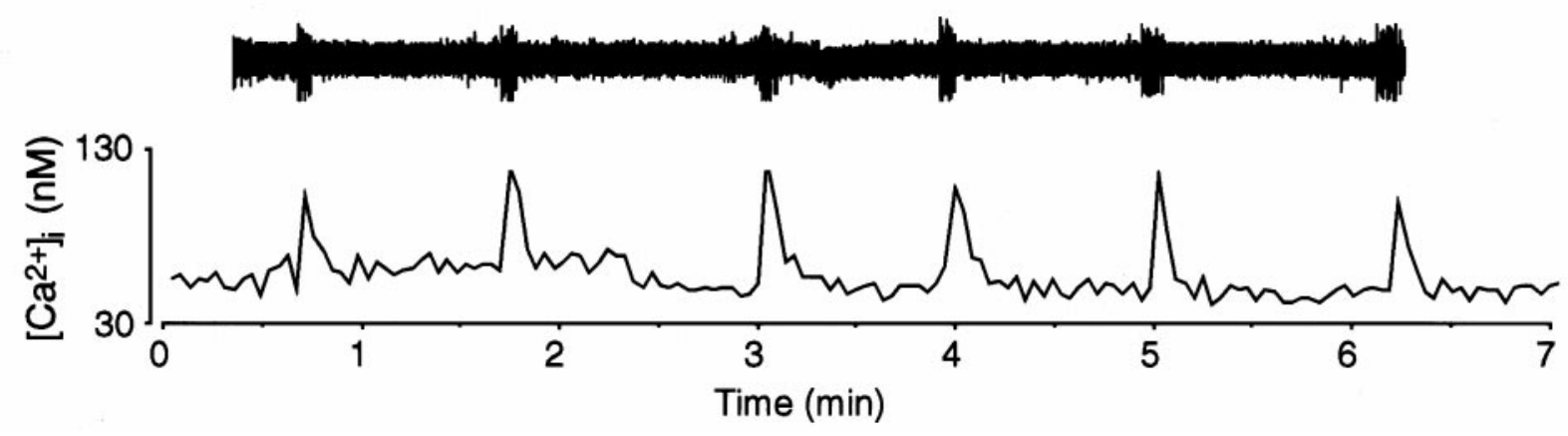

Figure 1. A, A field of cells in the GCL of an E16 chick retina that has been loaded with fura- 2 AM dye and visualized with a $63 \times$ objective under 380 $\mathrm{nm}$ illumination. Scale bar, $40 \mu \mathrm{m}$. B, Spontaneous $\left[\mathrm{Ca}^{2+}\right]_{\mathrm{i}}$ elevations in three cells that are indicated by numbered arrows in $A$. Note the large amplitude and the periodic and synchronized nature of the bursts. $C$, Simultaneous optical (bottom) and extracellular (top) recordings of a GCL cell in an E15 retina. Each $\left[\mathrm{Ca}^{2+}\right]_{\mathrm{i}}$ elevation corresponds to a simultaneous burst of action potentials.

\section{Retinal ganglion cells participate in synchronous spontaneous activity}

The GCL contains both RGCs and displaced amacrine cells (for review, see Mey and Thanos, 1992). To determine whether at least some of the spontaneously active cells were RGCs, we recorded from morphologically identified cells in the GCL that were transfected previously with DNA coding for GFP. The expression of GFP and its cytoplasmic distribution in GCL cells revealed dendritic and axonal structure within $12 \mathrm{hr}$ of transfection (Fig. $2 A-C$ ). Calcium imaging was then performed at high power on GFP-transfected retinae. Figure $2 D$ shows a high-power $(40 \times)$ field of fura-labeled cells, whereas Figure $2 E$ shows the GFP-labeled cells in the same field. The absorption and emission spectra of GFP and fura-2 are nonoverlapping, and the expression of GFP did not appear to affect the spontaneous activity of the transfected cells. As shown in Figure $2 F$, GFP-positive cells exhibited patterns of activity similar to those in untransfected retinae. In addition, GFP-positive cells (Fig. $2 F$, cells 1 and 2) had activity patterns similar to (and synchronous with) their GFPnegative neighbors in the same field (Fig. $2 F$, cell 3). Many of the labeled cells exhibiting spontaneous activity were RGCs, as evidenced by the presence of an axon (data not shown).

These experiments also afforded an opportunity to examine whether activity patterns exhibited by individual RGCs varied with their morphology. We observed that RGCs of different morphologies have activity patterns that did not differ markedly from each other (Fig. 2E,F, cells 1 and 2); neighboring cells, regardless of morphology, burst synchronously. Thus we conclude that RGCs are among the spontaneously bursting cells in the chick retina and also that their activity patterns do not vary according to their cell class.

To assess further whether all neighboring cells exhibit synchronized activity, we analyzed optical images of the entire fields before and during a synchronized burst. This is significant because although ganglion cells adjacent to each other in the retina project to closely adjacent tangential positions on the tectal retinotopic map, they project to distinct retinorecipient laminae (Ramon y Cajal, 1892; Ehrlich et al., 1987; Keyser et al., 1988; Yamagata and Sanes, 1995b). Figure 3 (left) shows $380 \mathrm{~nm}$ images of fura-2-loaded high-power fields of E13 and E16 retinae that were captured just before the onset of a wave. We then generated difference images in which an image captured at the peak of a burst was subtracted from the one captured just before the burst. Thus, only cells undergoing an increase in $\left[\mathrm{Ca}^{2+}\right]_{\mathrm{i}}$ across this period are visualized. The difference image (Fig. 3, middle) and the starting fura-2 image were virtually identical, demonstrating that all the cells in the GCL were "recruited" during a burst. To test the efficacy of this analysis, we subtracted fura-2 images captured in the interval between bursts from each other. As expected, no signals were present in these difference images (Fig. 

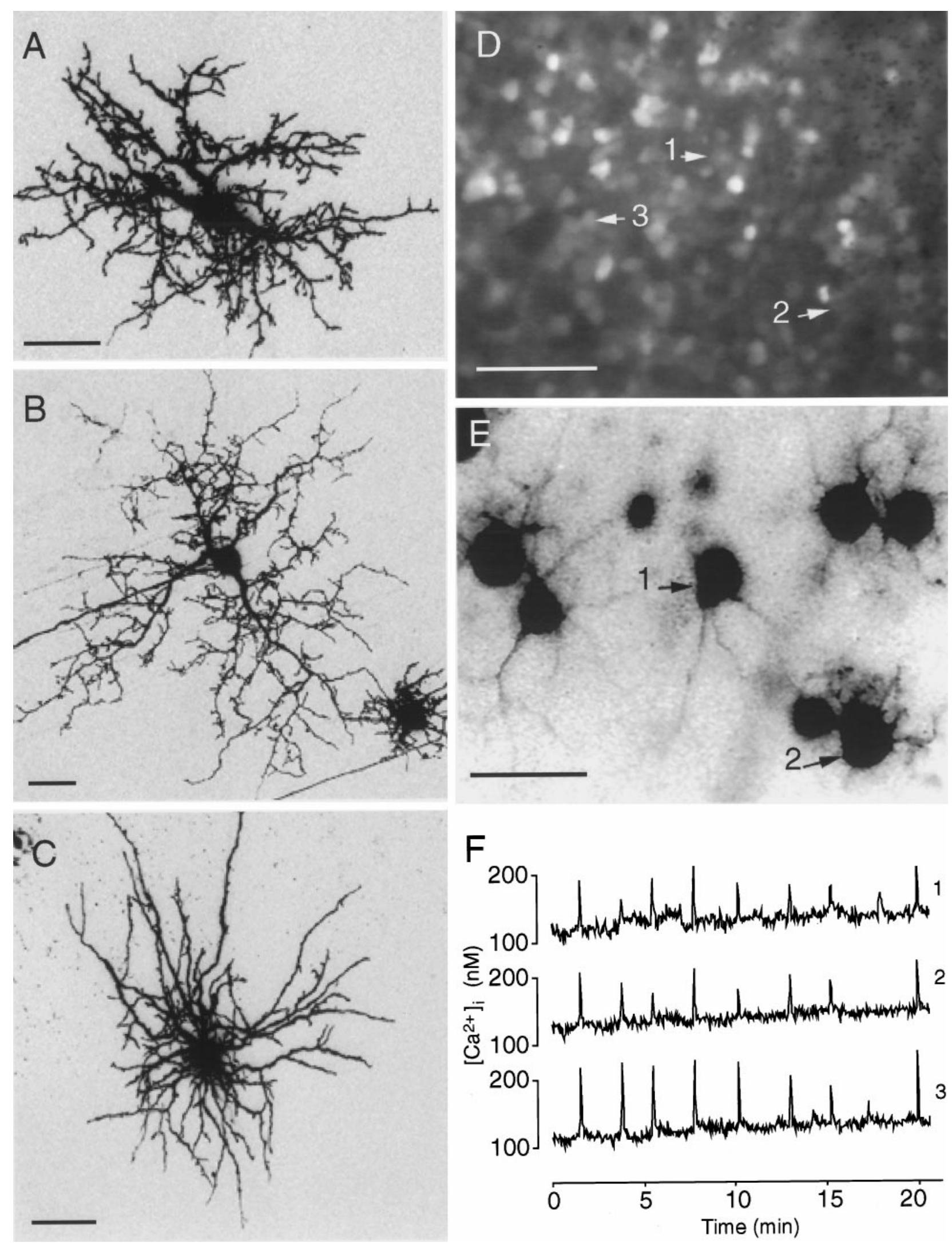

Figure 2. $A-C$, Examples of retinal ganglion cells from E13 to E14 retinae that have been transfected with green fluorescent protein using particle-mediated gene transfer and imaged $12 \mathrm{hr}$ after transfection using confocal microscopy. Scale bar, $50 \mu \mathrm{m}$. $D, E$, SIT camera images of a high-power field of GCL cells in an E15 retina that has been labeled with fura-2 AM $(D)$ and transfected with GFP $12 \mathrm{hr}$ before optical recording $(E)$. $F$, Optical recordings of spontaneous $\left[\mathrm{Ca}^{2+}\right]_{\mathrm{i}}$ elevations exhibited by cells indicated by numbered arrows in $D$ and $E$. Cells 1 and 2 are GFP-positive cells, each with a different dendritic morphology, whereas cell 3 was untransfected. All three cells share similar patterns of synchronous bursting activity. 


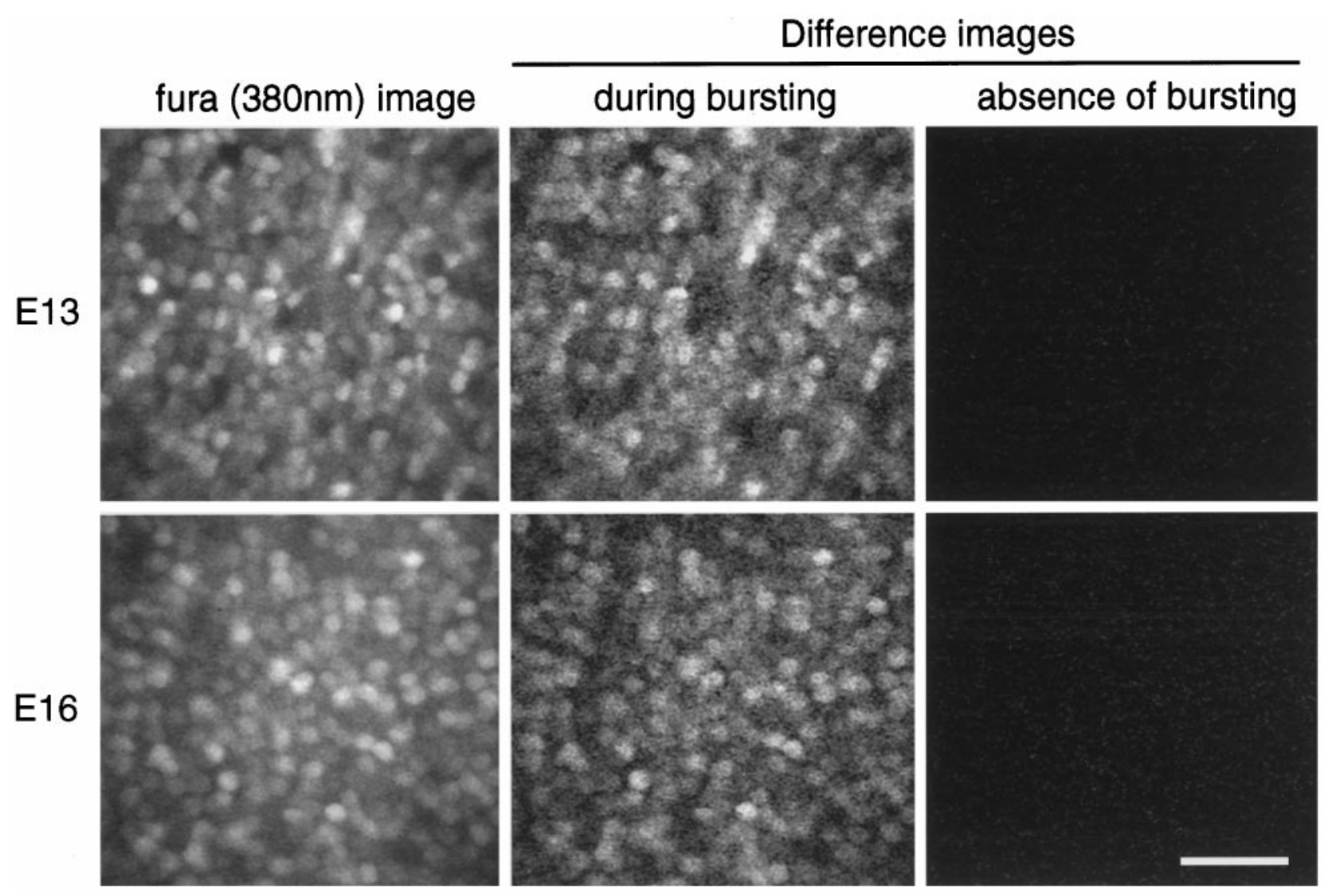

Figure 3. Uniform participation of GCL cells in synchronized spontaneous bursting activity. Left, High-power field of cells in the GCL of E13 and E16 chick retinae loaded with fura-2 AM dye and visualized under $380 \mathrm{~nm}$ illumination. Middle, Difference images that were generated by subtracting a 380 $\mathrm{nm}$ image at the peak of a burst from the one just before the onset of a burst. These images report on which cells underwent changes in [Ca $\left.{ }^{2+}\right]_{\mathrm{i}}$ between the two time points. Because these difference images are virtually identical to the baseline fura- 2 image, they indicate that all the cells in the field underwent $\left[\mathrm{Ca}^{2+}\right]_{\mathrm{i}}$ elevations synchronously. Right, Difference images generated by subtracting a $380 \mathrm{~nm}$ image from its subsequent image in the period between bursts. The absence of any prominent signal indicates that all the cells in the field are uniformly quiescent between consecutive bursts. The threshold and brightness/contrast settings for the subtraction images were identical. Scale bar, $50 \mu \mathrm{m}$.

3, right). This result was consistent over multiple retinae and over prolonged periods of bursting activity. Taken together, these results show that although activity between cells in the two eyes and among cells far apart in the same eye is unlikely to be synchronized, activity patterns are highly correlated among neighboring cells of different morphological classes. As such, differences in laminar specifications between closely adjacent cells are unlikely to be accounted for by their activity patterns.

\section{Spatial patterns of spontaneous retinal activity}

We imaged $4 \times 4 \mathrm{~mm}$ fields at lower magnification $(2.5 \times)$ to better analyze the spatial distribution of the spontaneous bursts of activity. Each burst corresponded to a propagating wave that moved continuously across large areas of the retina. Figure 4 shows three such waves, all recorded from a single piece of retina over a 15 min period. The waves propagated at speeds of $0.5-1.5$ $\mathrm{mm} / \mathrm{sec}$ ( $n=30$ waves in four retinae). The area traversed by each wave often extended over the majority of the field, with the width of the waves measuring $0.5-2 \mathrm{~mm}$ at the point of their maximum extent. Successive waves sometimes originated at different points on the retina, including the middle (Fig. $4 A$ ), edge (Fig. $4 B$ ), or corner (Fig. $4 C$ ) of the retinal piece. The direction also varied from one wave to the next and sometimes even during the course of a single wave; some waves took meandering paths across the retina (Fig. $4 C$ ). However, waves did not "double back" across their own paths to return to portions of the retina they had traversed previously. This suggests that bursting activity renders GCL cells refractory to subsequent activation for a considerable period. This refractory property is also suggested by the regular periodicity of bursting exhibited by individual cells observed at high power; cells never burst twice in rapid succession as would result if a wave turned back to propagate through its own wake.

\section{Developmental regulation of correlated spontaneous activity}

To determine whether synchronized spontaneous bursting activity was developmentally regulated, we recorded from retinae isolated from staged embryos. We began our observations at the time that the GCL delaminates from the ventricular zone above the interplexiform layer at E7.5 (Hughes and LaVelle, 1974; Mey and Thanos, 1992). Both high- and low-power recordings ( $n=3$ retinae) failed to reveal prominent rhythmic bursting activity $(>50 \mathrm{~nm})$ at this early stage. Changes in $\left[\mathrm{Ca}^{2+}\right]_{\mathrm{i}}$ were confined to low-amplitude fluctuations $(<50 \mathrm{~nm})$ that did not rise markedly above baseline (Fig. 5A). Likewise, high- and low-power recordings from E11 retinae $(n=11)$ did not reveal the synchronous, large-amplitude $\left[\mathrm{Ca}^{2+}\right]_{\mathrm{i}}$ elevations described for E16 retinae.

Synchronized, large-amplitude, rhythmic activity and propagating waves were found at $\mathrm{E} 13$ ( $n=4$ retinae), E14 $(n=5), \mathrm{E} 15$ 

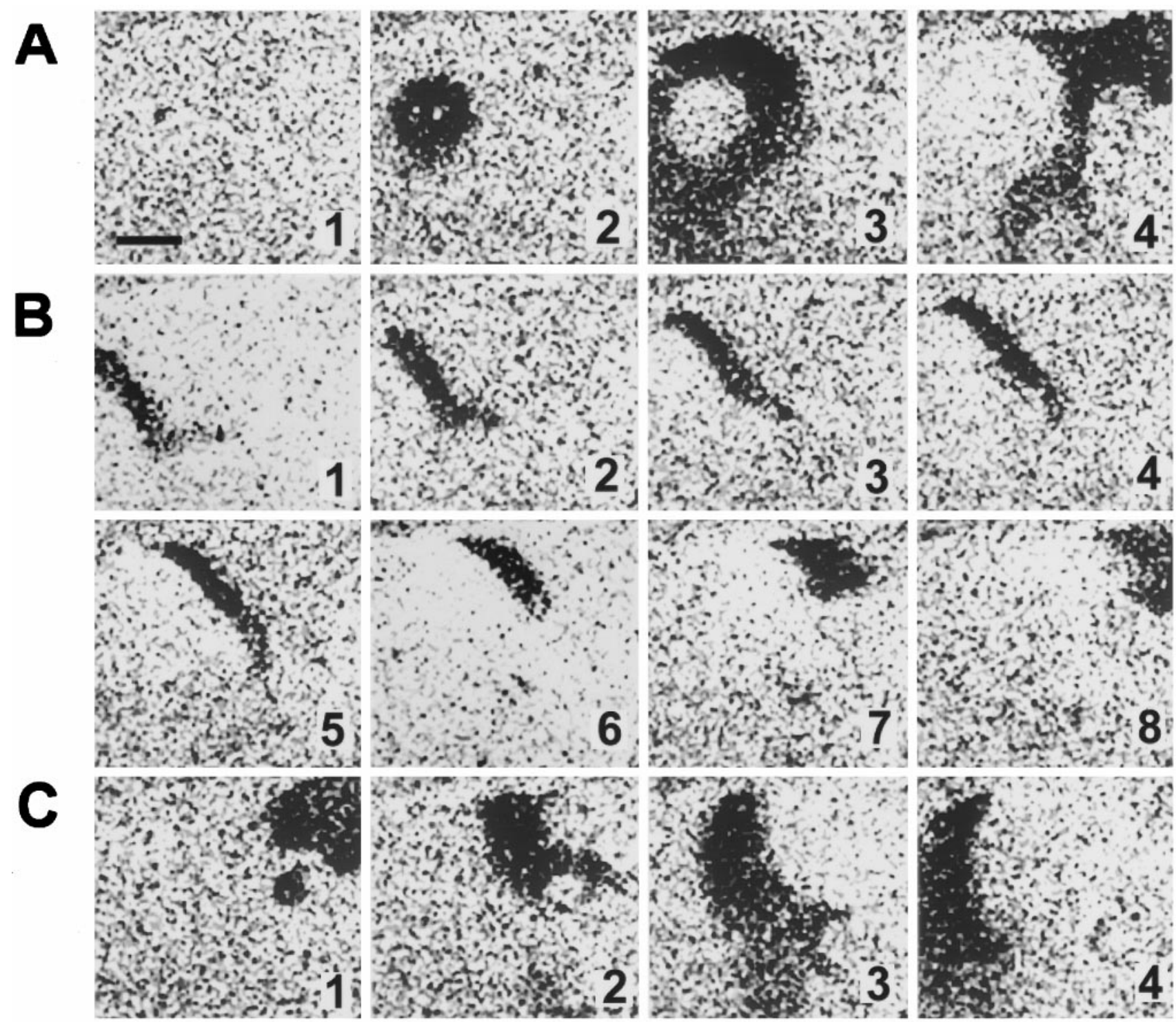

Figure 4. Propagation of spontaneous activity as waves. Images were visualized with a $2.5 \times$ objective at $380 \mathrm{~nm}$ excitation and were captured every 1.4 sec; eight frames were averaged for each image. Consecutive images were then subtracted from each other to show the changes in spatial distribution of activity from one image to the next. Because the intensity of the $380 \mathrm{~nm}$ signal decreases when $\left[\mathrm{Ca}^{2+}\right]_{\mathrm{i}}$ increases, the darker regions in the images correspond to recently active regions. $A-C$, Subtracted images of three separate waves recorded from the GCL of a single E16 retina in the course of a 15 min recording. Consecutive images correspond to time points $1.4 \mathrm{sec}$ apart. Note the variable points of origin, directions of travel, and speeds of propagation of the waves. Scale bar, $1 \mathrm{~mm}$.

$(n=22), \mathrm{E} 16(n=25), \mathrm{E} 17(n=1)$ and $\mathrm{E} 18(n=3)$. Figure $5 B$ illustrates the pattern recorded in two representative cells from a single E15 retina. Recordings from E20 $(n=3)$, postnatal day 0 (P0) $(n=5)$, and P1 $(n=2)$ retinae revealed a different pattern of activity (Fig. 5C). Only a fraction of cells (7-17\%) examined at high power displayed large periodic $\left[\mathrm{Ca}^{2+}\right]_{\mathrm{i}}$ elevations $(>50 \mathrm{nM})$, whereas the remainder were either relatively quiescent or displayed occasional sporadic bursts. The $\left[\mathrm{Ca}^{2+}\right]_{\mathrm{i}}$ elevations observed tended to be more prolonged, lasting up to $1-2 \mathrm{~min}$ in duration (compare Fig. $5 B$ with $C$ ). Also, these periodic $\left[\mathrm{Ca}^{2+}\right]_{i}$ elevations varied in frequency and were often asynchronous with those occurring in neighboring cells. Prominent periodic wavelike propagations like those observed in E13-E18 retinae were not present. A summary of the developmental changes in the fraction of cells exhibiting large-amplitude, rhythmic bursting activity in retinae from E7.5 to P1 is presented in Figure 5D.
To quantitate further the developmental changes in spontaneous bursting behavior, we calculated the burst frequency of cells in E11, E16, and P0 retinae (Fig. 6A; three retinae at each age were analyzed; 64 cells per retina). Although cells in each E16 retina were completely uniform in their bursting rate, cells in each E11 and P0 retina had widely varying frequencies, with a substantial fraction of cells lacking bursting activity altogether. To quantitate the degree of synchrony that exists between active cells, we computed the correlation coefficients between pairs of active cells in each retina (see Materials and Methods). Figure $6 B$ shows the distribution of correlation coefficients for cell pairs for the same three ages. The degree of synchrony between cells in E16 retinae was markedly greater than that found in E11 or P0 retinae. Thus, both the frequency and the synchrony of spontaneous bursting are developmentally regulated, with activity being most prominent and synchronized from the ages of E13-E18. 

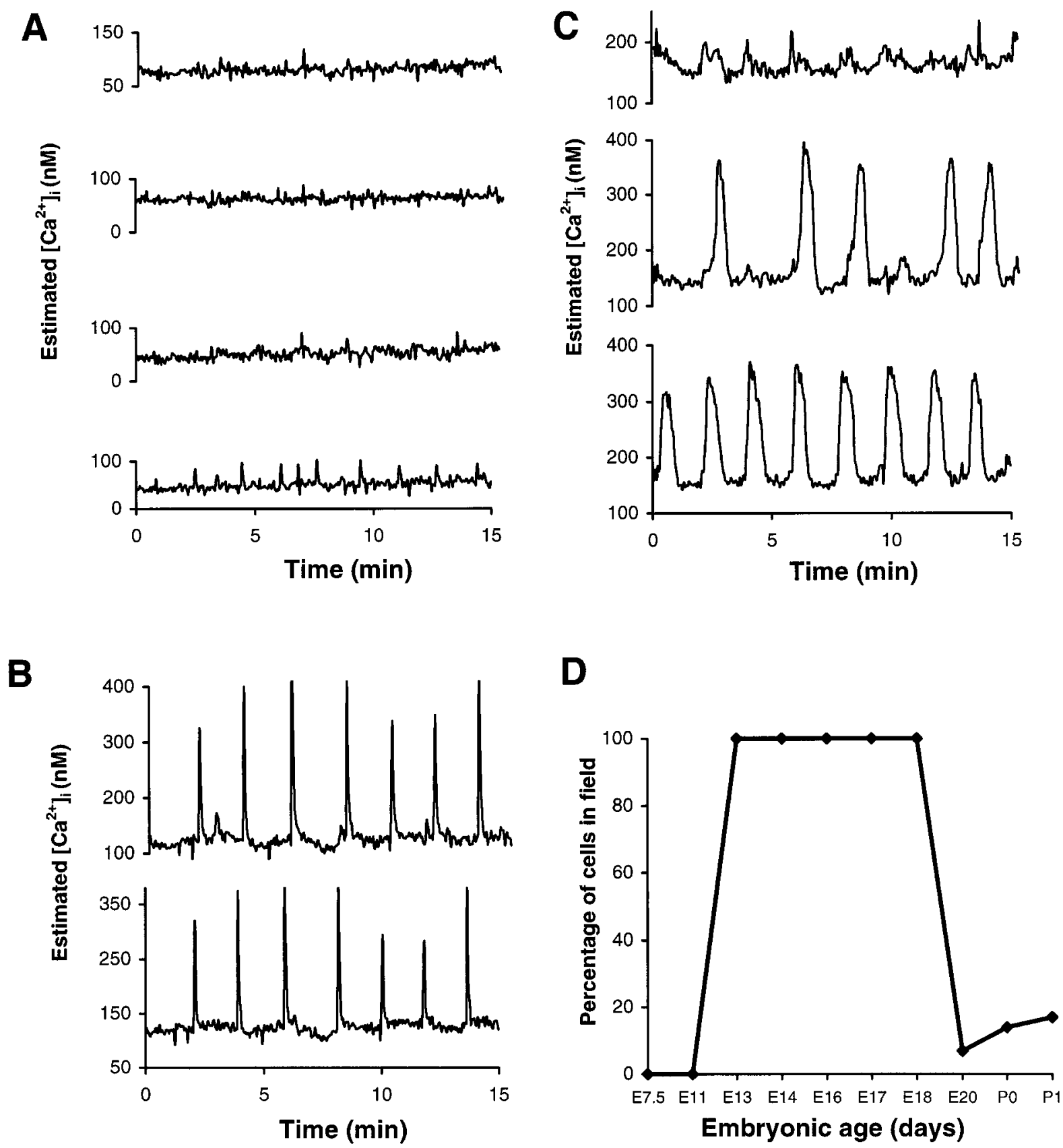

Figure 5. Spontaneous activity in the GCL at different developmental stages in embryonic development. $A-C$, The plots show representative recordings of individual cells from the same field of view in an E7.5 $(A)$, E15 $(B)$, and P0 $(C)$ retina. $D$, Summary of developmental changes in the fraction of cells exhibiting prominent, rhythmic activity is shown. The percentage of cells exhibiting prominent rhythmic $\left[\mathrm{Ca}^{2+}\right]_{\mathrm{i}}$ elevations $(>50 \mathrm{nM})(\mathrm{such}$ as those shown in $B)$ was plotted for each developmental age; 64 cells were scored for each retina $($ E7.5 = 128 cells, E11 = 320 cells, E13 = 128 cells, E14 = 128 cells, E16 $=640$ cells, E17 $=64$ cells, E18 $=64$ cells, E20 $=128$ cells, P0 $=256$ cells, and P1 $=64$ cells). The plot highlights the period between E13 and E18 as the ages during which rhythmic, synchronized activity is most prominent.

\section{Neurotransmitter regulation of correlated spontaneous activity}

To assess how correlated spontaneous activity is regulated by neurotransmitter-mediated communication, we applied antagonists to neurotransmitter receptors on E16 retinae and examined the activity of single cells before, during, and after drug application.

Antagonists to glutamatergic receptors decreased bursting activity markedly. Application of either NBQX $(10 \mu \mathrm{M})$, an AMPA/ kainate receptor antagonist, or APV $(100 \mu \mathrm{M})$, an NMDA receptor antagonist, decreased bursting frequency significantly. However, the bursts occurring in neighboring cells remained synchronous as before drug application. When the two antagonists were applied together, spontaneous bursting was completely eliminated (Fig. 7). Inhibition was reversible because bursting activity can be restored after washing out the antagonists by a continuous flow of Ringer's solution for $30 \mathrm{~min}$. This result indicates that spontaneous bursting is dependent on glutamater- 
E11

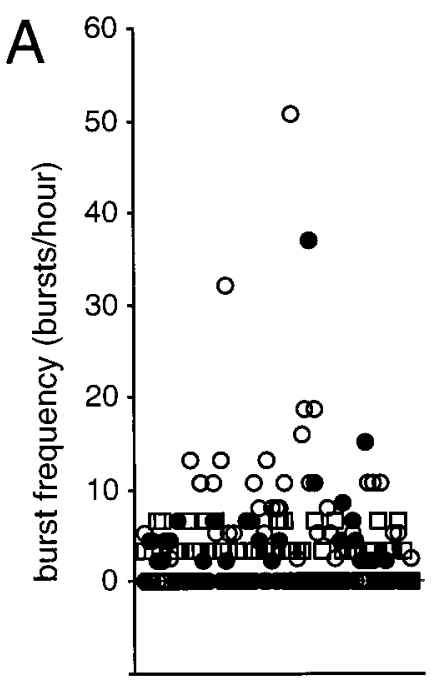

B

Figure 6. A, Distribution of burst frequencies in GCL cells of E11, E16, and P0 retinae as analyzed from optical recordings. Three retinae (64 cells per retinae) were analyzed for each age; symbols (open and closed circles and squares) indicate cells from the same retina. Cells in individual E11 and P0 retinae are highly variable in their bursting frequency, whereas cells from E16 retinae burst at an uniform rate. $B$, Distribution of Spearman's rank correlation coefficients in bursting events as assessed for pairs of GCL cells for the same retina. Three retinae were analyzed at each age; 20 pairs of cells were assessed in each retina. Note that activity patterns between cells are best correlated (coefficient $>0.6$ ) at E16.

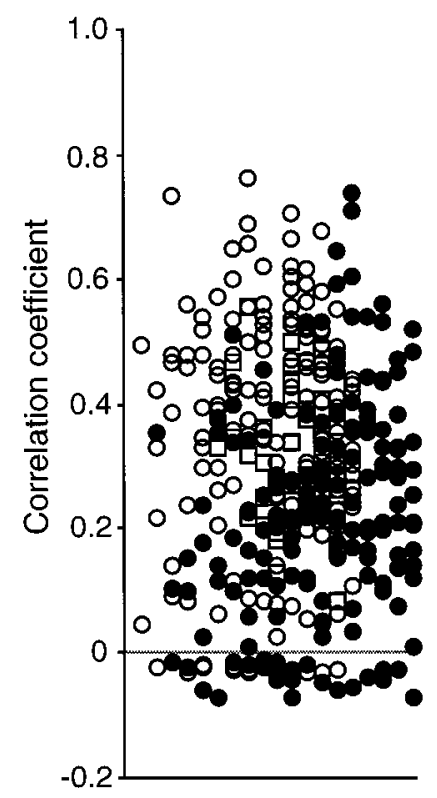

E16

PO
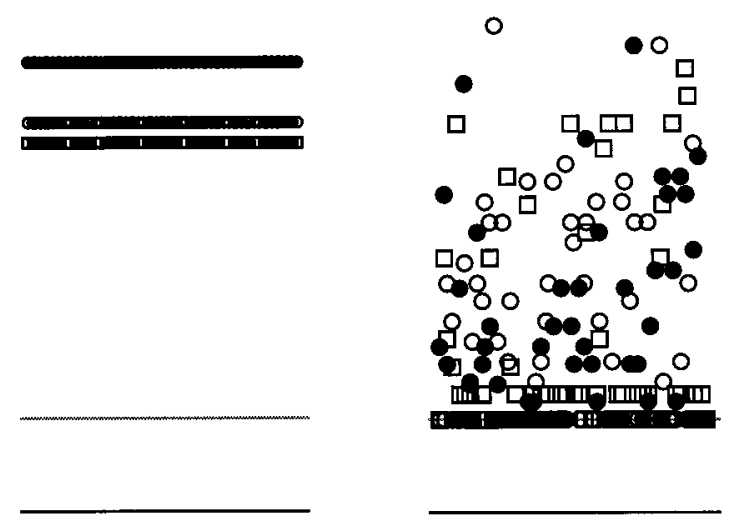

E16

PO

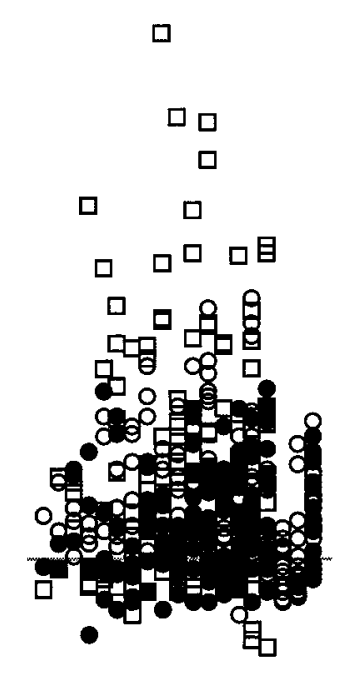

gic transmission mediated via both NMDA and non-NMDA glutamate receptors.

In contrast, bicuculline $(150 \mu \mathrm{M})$, a $\mathrm{GABA}_{\mathrm{A}}$ receptor antagonist, increased bursting frequency, again without affecting the synchronized nature of the bursts (Fig. $8 A$ ). Conversely, the application of strychnine, a glycine receptor antagonist, decreased bursting frequency (Fig. $8 B$ ). The effects of both bicuculline and strychnine were reversible (Fig. 8A,B). These results suggest that both GABAergic and glycinergic neurotransmission modulate bursting activity by suppressing and potentiating it, respectively.

Inhibition of cholinergic neurotransmission using the neuronal nicotinic acetylcholine receptor antagonists hexamethonium (100 $\mu \mathrm{M}$ ) and mecamylamine (up to $160 \mu \mathrm{M}$ ) had little effect on the bursting behavior (Fig. 9). These classical "ganglionic blockers" have been demonstrated in earlier patch-clamp studies to successfully block acetylcholine-induced currents in neonatal rat retinal ganglion cells (Lipton et al., 1987). Application of the acetylcholine receptor agonist nicotine at levels sufficient to desensitize the receptor (1 mM) also failed to eliminate bursting activity (data not shown).

The quantitative effects of neurotransmitter antagonists on bursting frequency are summarized in Figure 10. In all cases, the modulation of frequency by the application of antagonists did not affect the synchronization of activity between cells; all cells participated in correlated bursting regardless of the frequency of bursts. Taken together, our results indicate that although neurotransmission plays a major role in potentiating and modulating bursting activity, neurotransmission is unlikely to mediate the synchronization of activity between cells. 

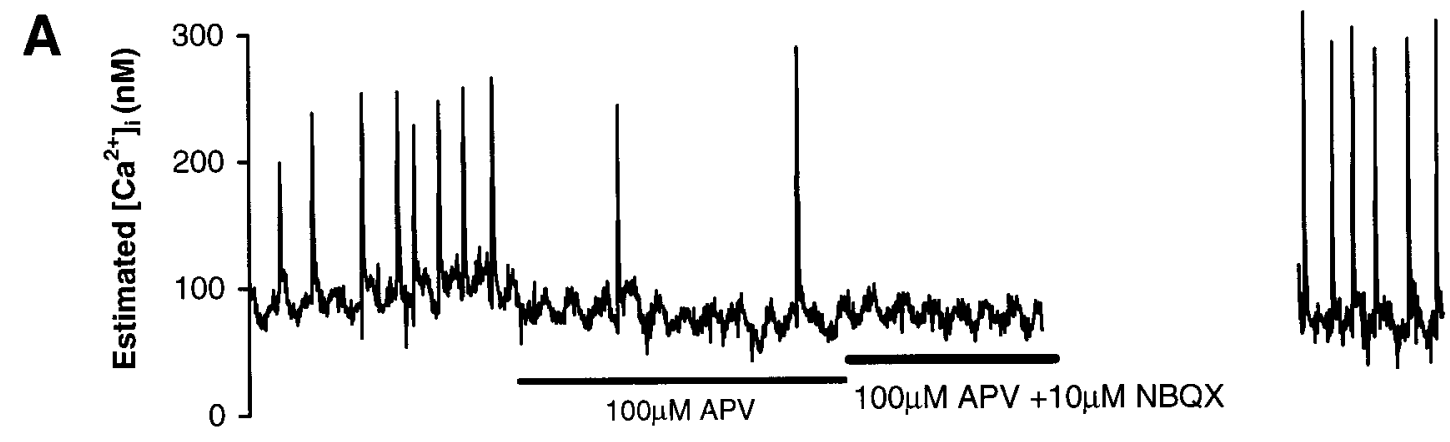

B
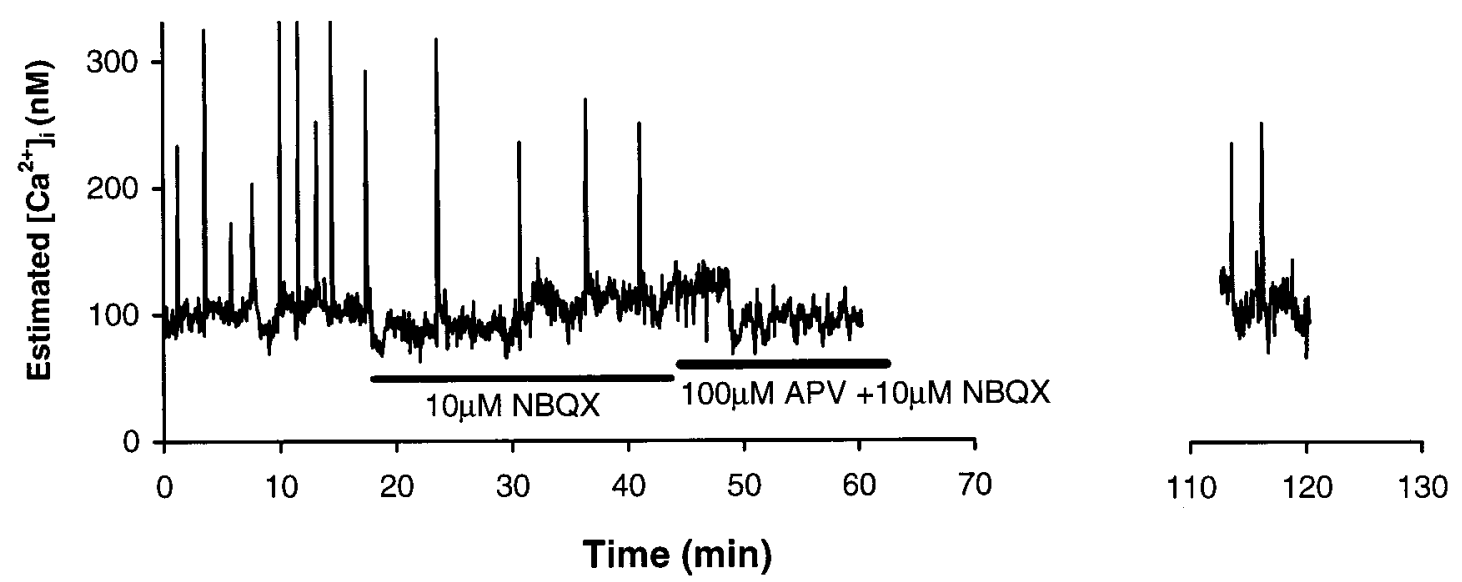

Figure 7. Recordings from representative cells in E16 retinae showing the effect of glutamate receptor antagonists on spontaneous bursting activity. APV $(A)$, an NMDA receptor antagonist, and NBQX $(B)$, a non-NMDA receptor antagonist, each decreased burst frequency when applied alone and obliterated activity when applied in combination.

\section{Role of gap junctional communication}

The wave-like properties of spontaneous activity implies that excitation spreads from cell to cell in the GCL. One candidate mechanism for this process involves gap junctional communication in the horizontal plane of the retina. To assess the involvement of gap junctions in spontaneous bursting, we applied gap junction blockers to spontaneously active retinae of E16 embryos. We used three different glycyrrhetinic acid compounds that have been demonstrated to block gap junctions with high potency and low toxicity by altering connexon particle packing in gap junction plaques (Goldberg et al., 1996). The ability of these agents to block gap junctions has been shown previously using physiological (Nedergaard et al., 1995; D’Andrea and Vittur, 1996; Frame and de Feijter, 1997), biochemical (Davidson et al., 1986; Davidson and Baumgarten, 1988), and morphological (Nedergaard et al., 1995; D'Andrea and Vittur, 1996; D. I. Vaney, personal communication) assays. All three inhibitors used exerted strongly suppressive but readily reversible effects on spontaneous bursting [18 $\alpha$-glycyrrhetinic acid ( $n=2$ retinae), $18 \beta$-glycyrrhetinic acid ( $n=4$ retinae), and carbenoxylone ( $n=2$ retinae)] (Fig. $11 A-C)$. Lower concentrations of the inhibitors $(25 \mu \mathrm{M})$ were also effective in suppressing activity when the retina was incubated with the agents for 1-2.5 hr. The degree of suppression varied from cell to cell, with the majority of cells being strongly suppressed as shown for the top cell in Figure 11C. This unequal suppression of activity in neighboring cells raises the possibility that cells undergoing a burst may recruit their neighbors to generate a propagated wave of activity by communicating with them via gap junctions. To assess the specificity of action of the gap-junctional inhibitors used, we also tested glycyrrhizic acid, an inactive compound chemically related to the glycyrrhetinic acid inhibitors (Davidson et al., 1986). Glycyrrhizic acid, at concentrations up to $100 \mu \mathrm{M}(n=2$ retinae), had no marked effect on bursting activity (Fig. 11D). Taken together, these results not only reveal that gap junctions play a role in spontaneous bursting activity but also suggest that they may indeed mediate the horizontal spread of activity across the retina.

\section{DISCUSSION}

Coordinated spontaneous activity has recently been found in many parts of the developing CNS, most notably in the visual system (Galli and Maffei, 1988; Meister et al., 1991; Sernagor and Grzywacz, 1993, 1994; Feller et al., 1996; Mooney et al., 1996) but also in the auditory system (Lippe, 1994), neocortex (Yuste et al., 1992), and spinal cord (for review, see O'Donovan and Chun, 1997; Spitzer and Gu, 1997). The ubiquity and robustness of this phenomenon support the suggestion that it is important for refinement of connections in developing circuits. The highly patterned nature of spontaneous activity raises the possibility that its spatial and temporal features are essential to reorganization of connectivity. Here, we have characterized spontaneous activity in the GCL of the embryonic chick retina. Our analysis of the patterns of activity and of their developmental regulation allows us to implicate waves of activity as potential modulators of some aspects of visual development but argues against their involvement in others. Our analysis of the chemical and electrical mechanisms underlying the waves leads us to propose a simple model that explains major features of their generation and propagation. 

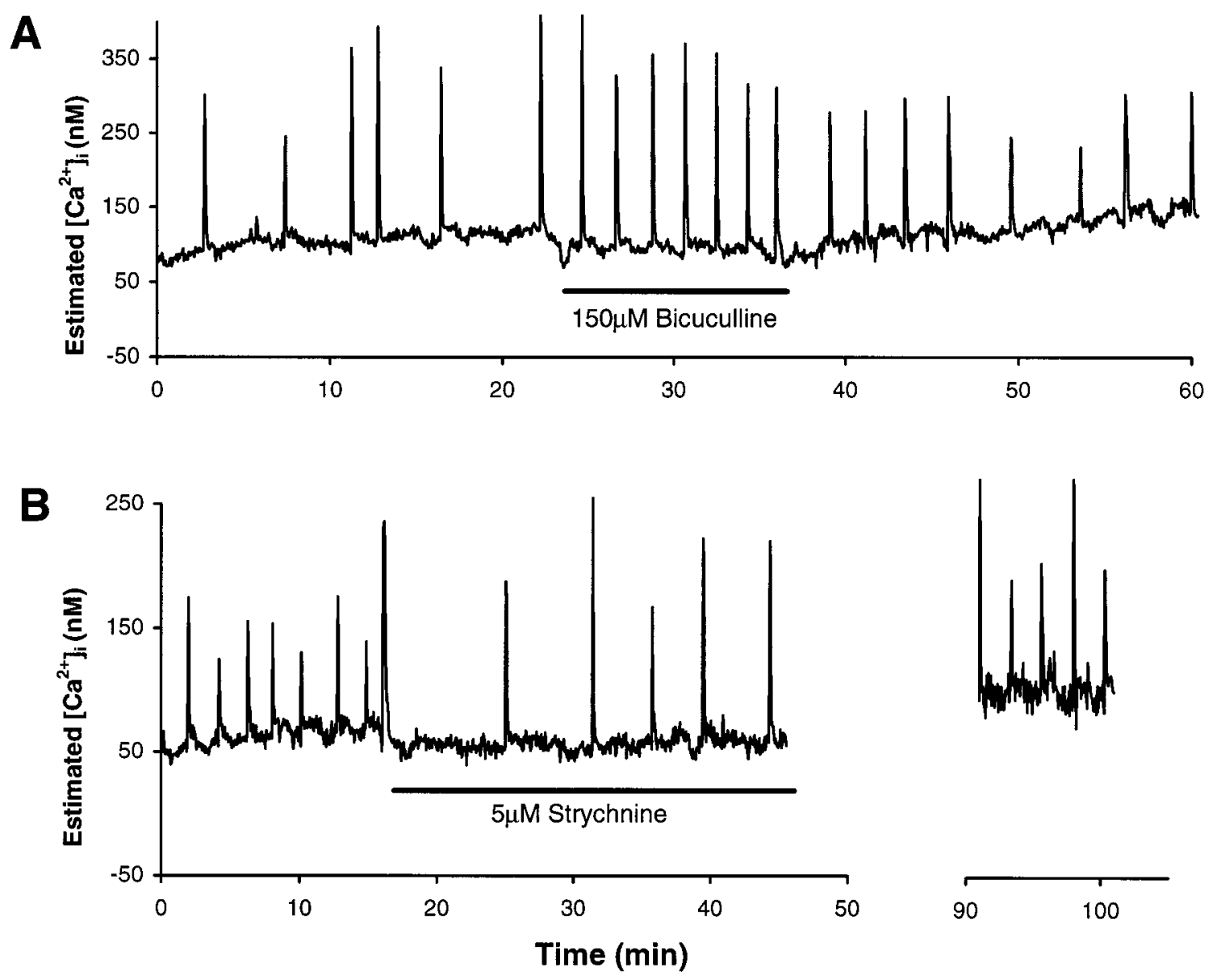

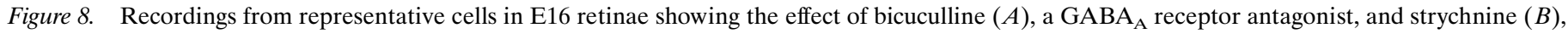
a glycine receptor antagonist, on spontaneous bursting activity. Effects of both bicuculline and strychnine were reversible after washout of the drugs.

\section{Activity-dependent regulation of development in the chick retina}

Although some spontaneous activity can be detected as early as E7 (see also Catsicas et al., 1998), it is especially prominent and synchronized in the period spanning E13-E18. It is precisely during this period that connections in the developing chick visual system are reorganized. First, retinotectal projections are refined from an imprecise system to a precise retinotopic map between E13 and approximately E16 (Nakamura and O'Leary, 1989). Inhibition of activity by intraocular injections of activity blockers during this period (E13, E14, and E15) perturbed the retinotopic refinement process (Kobayashi et al., 1990). Second, ipsilateral projections from the retina to the brain from the isthmo-optic nucleus to the retina are primarily eliminated between E12 and E17 (O'Leary and Cowan, 1982; O'Leary et al., 1983). Interference with the production or reception of retinal activity during this period retarded the elimination of these projections (O'Leary and Cowan, 1984; Pequignot and Clarke, 1992b; Wu et al., 1994). In addition, $40 \%$ of retinal ganglion cells die between E11 and E18 (Rager and Rager, 1976, 1978; Hughes and McLoon, 1979; Kobayashi, 1993), and inhibition of retinal activity during this period deferred the period of naturally occurring cell death (Kobayashi, 1993). The spontaneous activity patterns we have described in this work are likely to be the substrate to which the above mentioned interventions were directed. Likewise, correlated spontaneous activity in the ferret retina occurs concurrently with the remodeling of retinal axons in the thalamus and loses its patterned nature just before eye opening (Wong et al., 1993). These parallel trends conserved across species are suggestive of developmental mechanisms that act to circumscribe correlated bursting to the period in which synchronized activity is functionally relevant.

\section{What can the spatial and temporal patterns of spontaneous activity encode?}

The regular periodicity of the bursts, the sparseness of bursting events (elevations of 12-14 sec duration separated by intervals of $\sim 2 \mathrm{~min}$ ), the rapid speed of the waves, and the large numbers of cells covered by each wave, all indicate that even though bursting events are synchronized between neighboring cells within one retina, they are unlikely to be synchronized between cells from corresponding points in two retinae. Therefore, target cells in the brain may be able to distinguish signals originating in one eye from those originating in the other. Such signals could be important for the elimination of transient ipsilateral projections (O'Leary et al., 1983). In addition, the wave-like spread of bursting activity enables bursting events to be more tightly synchronized between cells that are close neighbors than between those that are widely separated. As a result, target cells may distinguish afferent signals based on intercellular separation between the retinal ganglion cells producing the signals. Such signals can direct the topographical refinement of the retinotectal map (Na- 
A

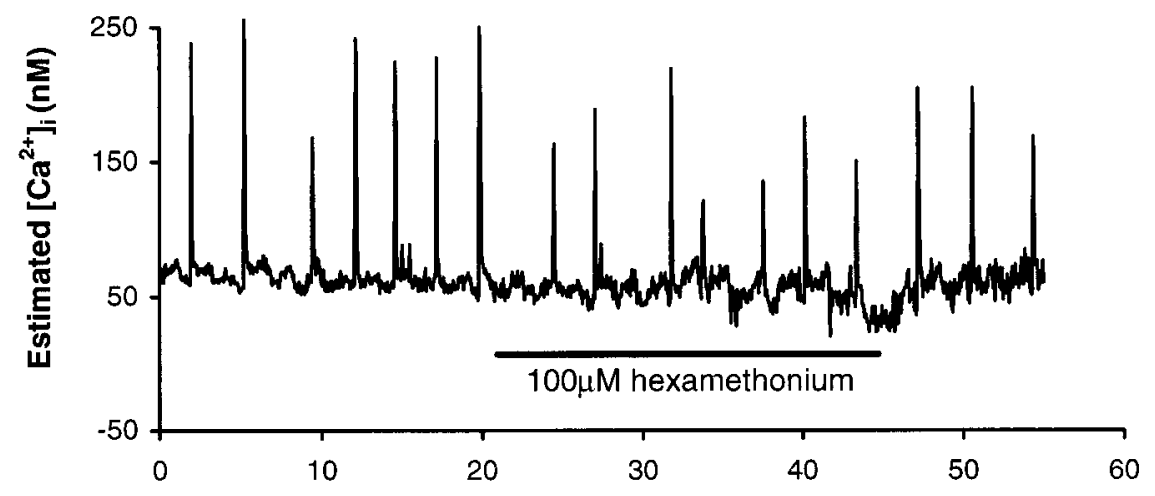

B

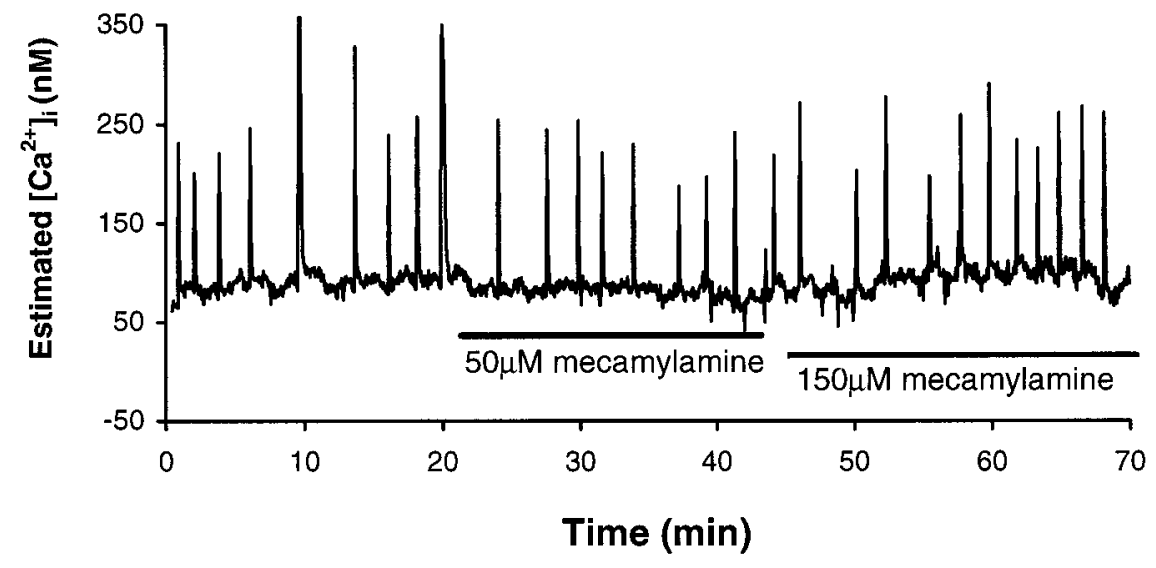

Figure 9. Recordings from representative cells in E16 retinae showing that neither hexamethonium $(A)$ nor mecamylamine $(B)$, two neuronal nicotinic acetylcholine receptor antagonists, significantly affected spontaneous bursting activity. kamura and O'Leary, 1989). Thus, spontaneous activity patterns could encode both binocular and intraocular differences. In addition, spontaneous activity may have intraretinal significance. Previous studies have implicated activity in the development of dendritic morphology (Bodnarenko and Chalupa, 1993; Bodnarenko et al., 1995) and receptive field properties (Sernagor and Grzywacz, 1996; Burgi and Grzywacz, 1997). Thus, it is possible that spontaneous activity in RGCs may be relevant to establishing afferent, in addition to efferent, connections.

These studies also provided us with an opportunity to evaluate the possibility that activity patterns account for the laminaspecific arborization of RGCs in the optic tectum. Chemically defined subsets of RGCs project to distinct laminae within the tectum (for references, see Yamagata and Sanes, 1995b). Although cell surface cues clearly enable recognition of retinorecipient laminae by RGCs in general (Yamagata and Sanes, 1995a; Inoue and Sanes, 1997), previous studies in mammals suggested that activity might play a role in targeting subsets of RGCs to individual retinorecipient laminae. In the ferret visual system, the axonal projections of functionally distinct ON and OFF RGCs are refined during development to occupy distinct sublaminae within the dorsal lateral geniculate nucleus. This refinement is driven by spontaneous retinal activity (Hahm et al., 1991; Cramer and Sur, 1997), and it is thought to arise from the temporal differences in the bursting patterns of ON and OFF RGCs (Wong and Oakley, 1996). In chick, however, we found that all RGCs are synchronously active in a retinal region that included cells projecting to all three retinorecipient laminae (Yamagata and Sanes, 1995b). Thus, although we cannot eliminate the possibility that laminar selectivity is modulated by activity, it is highly unlikely that differences in activity account for different laminar prefer-

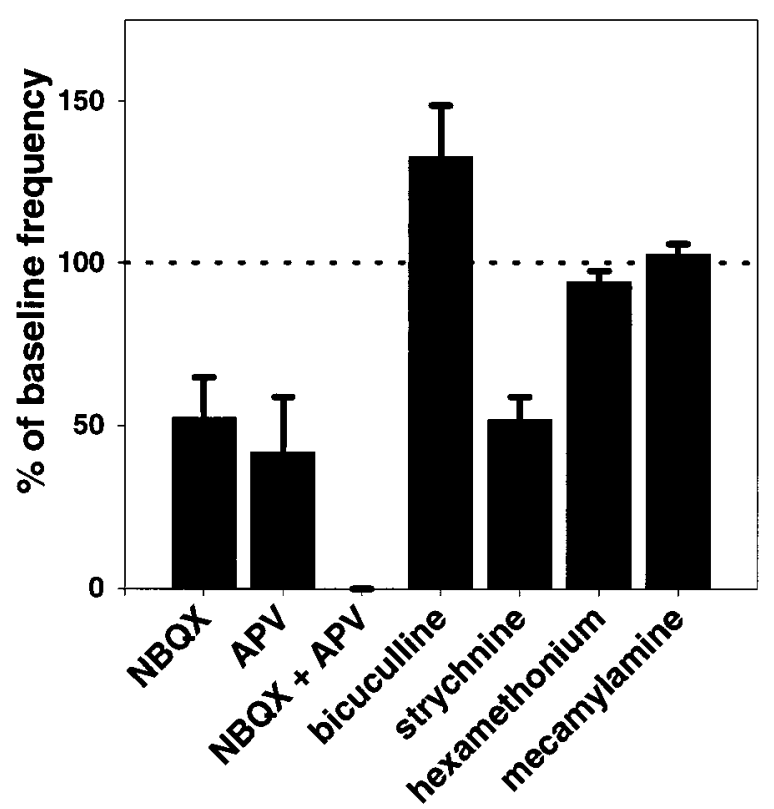

Figure 10. Summary of effects of receptor antagonists on spontaneous activity of E16 retinae, expressed as a percentage of the bursting frequency exhibited by cells in the same retina before drug administration. The bursting frequencies were computed from plots such as those given in Figures 7-9. The concentrations used were (in $\mu \mathrm{M})$ : NBQX, $10(n=3$ retinae); APV, $100(n=3)$; combination of APV and NBQX, 100 and 10 , respectively $(n=4)$; bicuculline, $150(n=6)$; strychnine, $5(n=3)$; hexamethonium, $100(n=3)$; and mecamylamine, $150(n=3)$. Activities of 64 cells were quantified in each retina. Error bars indicate SD. 

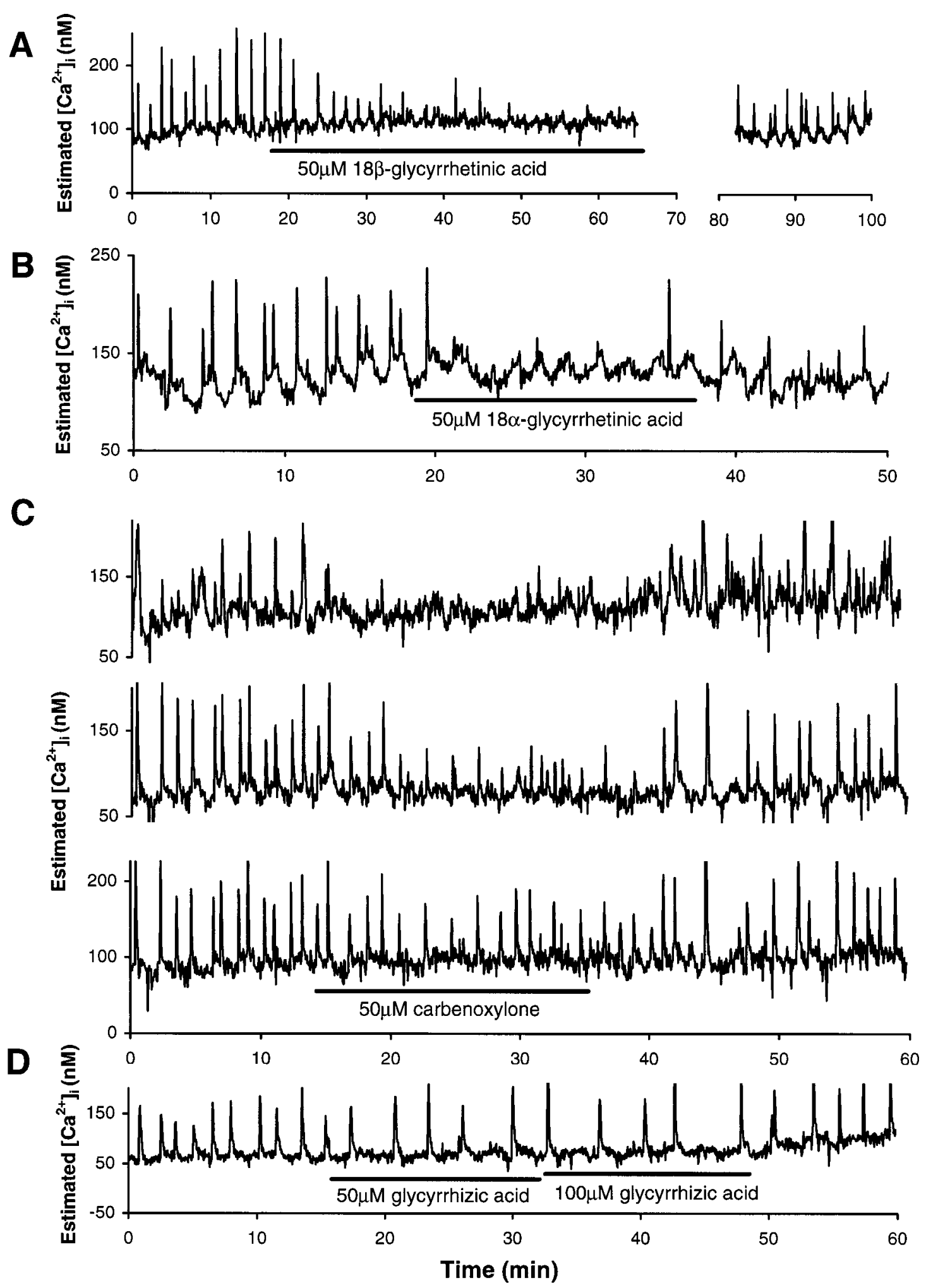

Figure 11. Recordings from representative cells in E16 retinae showing the strong suppressive effect of gap junctional inhibitors of the glycyrrhetinic acid family. $A, 18 \beta$-Glycyrrhetinic acid $(n=4$ retinae). $B, 18 \alpha$-Glycyrrhetinic acid $(n=2$ retinae). $C$, Carbenoxylone $(n=2$ retinae). The recordings in $C$ are obtained from neighboring cells in the same high-power field. $D$, Administration of glycyrrhizic acid $(n=2$ retinae), a chemically related compound that is inactive in blocking gap junctions, failed to suppress spontaneous activity significantly. 


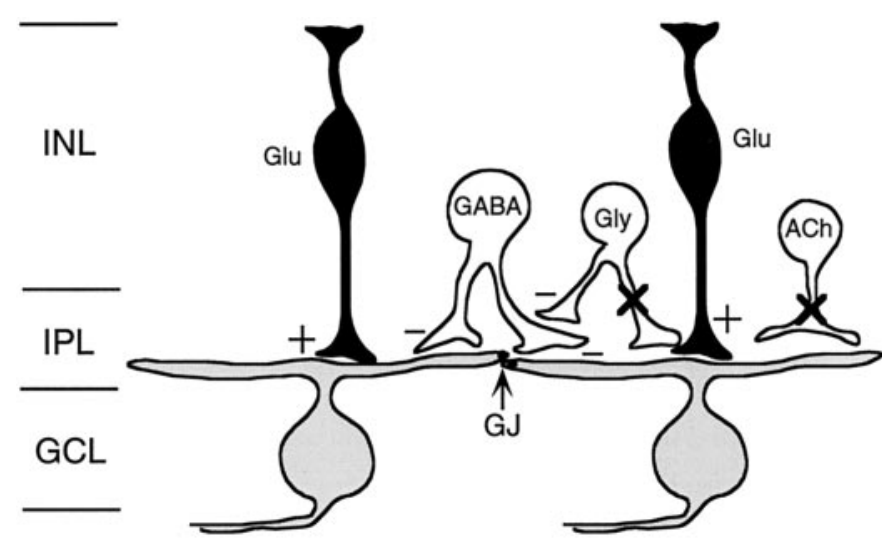

Figure 12. A model representing possible interactions in the inner retina underlying synchronized bursting activity in the E16 chick retina. Glutamate $(G l u)$-containing bipolar cells (black) provide the excitatory $(+)$ drive necessary for bursting activity in ganglion cells ( gray). GABAergic $(G A B A)$ amacrine cells (unfilled) modulate burst frequency suppressively by direct inhibition (-), whereas glycinergic (Gly) amacrine cells may potentiate bursting frequency indirectly by suppressing inhibitory GABAergic input. Glycinergic cells are likely to supply direct inhibitory inputs to ganglion cells, but these do not appear to influence bursting. Cholinergic $(A C h)$ amacrine cells are likely to be present but do not exert an effect on bursting activity. Crossed-out connections represent those that are likely to be present but do not influence bursting activity. Propagation of activity in the horizontal plane of the GCL may involve gap junctional $(G J)$ communication occurring between ganglion cells. INL, Inner nuclear layer; $I P L$, inner plexiform layer; $G C L$, ganglion cell layer.

ences exhibited by neighboring cells. Instead, we suggest that this matching is mediated by recognition molecules expressed by defined subsets of RGCs and their targets.

\section{Regulatory mechanisms underlying correlated spontaneous activity}

Our pharmacological experiments demonstrate that neurotransmitter-mediated communication is important in generating and/or modulating the frequency of spontaneous bursting. Figure 12 shows a possible model for the types of intercellular communications that may underlie spontaneous correlated bursting in the chick. The dependence of spontaneous correlated bursting on glutamatergic transmission suggests that bipolar cells, the only glutamatergic cells presynaptic to the cells in the GCL, exert an excitatory drive that permits or initiates spontaneous waves of activity. This drive is mediated by both NMDA and non-NMDA glutamate receptors. We also show that GABAergic and glycinergic amacrine cells modulate bursting behavior in ganglion cells by inhibiting and potentiating bursting frequency, respectively. Although GABAergic amacrines are likely to inhibit bursting directly, glycinergic amacrines can potentiate bursting frequency either directly, via an early excitatory effect of glycine (Cherubini et al., 1991), or more likely indirectly, via inhibiting GABAergic input.

The neurotransmitter regulation of spontaneous activity in chick retina is similar to that in the ferret in many respects but differs in a few significant ways. First, the presence of spontaneous bursting in early neonatal ferret is dependent on excitatory cholinergic input (Feller et al., 1996; Penn et al., 1998) and independent of ionotropic glutamatergic drive (Wong et al., 1995), the opposite of our observations in E16 chick retina. Second, although cholinergic amacrine cells in the ferret have been implicated in both providing the excitatory drive and mediating the lateral spread of excitation (Feller et al., 1996, 1997), the primar- ily vertical drive from glutamatergic bipolar cells in the chick is unlikely to by itself mediate the horizontal spread of excitation. Our results here suggest that gap junctional communication in the chick retina may act in this capacity, whereas this role is not apparent in the ferret retina (Wong, 1997). Finally, although the modulatory effect of GABA is similar in both species (Fischer et al., 1998), the role of glycine in the ferret is yet unclear and awaits future study.

Taken together, our results suggest that although intercellular communication in the retina is used in different species to regulate and propagate spontaneous wave-like activity, there may be considerable diversity across species in the precise mechanisms involved in generating and modulating this early activity pattern in the retina. Alternatively, the nature of neurotransmitter regulation may not be static across the period that activity waves are present and may change considerably as retinal circuits emerge and mature. Because we have performed our pharmacological analysis only on a single age (E16), it is possible that these apparent cross-species differences may be attributable to a comparison between systems at different stages of maturation (Sernagor and O’Donovan, 1997; Catsicas et al., 1998). Ongoing investigations in our laboratory are presently addressing the nature of developmental changes in neurotransmitter regulation of spontaneous bursting at different stages of maturation in the retina.

\section{REFERENCES}

Acheson DW K, Kemplay SK, Webster KE (1980) Quantitative analysis of optic terminal profile distribution within the pigeon optic tectum. Neuroscience 5:1067-1084.

Angaut P, Reperant J (1976) Fine structure of the optic fiber termination layers in the pigeon optic tectum: a Golgi and electron microscopy study. Neuroscience 1:93-105.

Bodnarenko SR, Chalupa LM (1993) Stratification of ON and OFF ganglion cell dendrites depends on glutamate-mediated afferent activity in the developing retina. Nature 364:144-146.

Bodnarenko SR, Jeyarasasingam G, Chalupa LM (1995) Development and regulation of dendritic stratification in retinal ganglion cells by glutamate-mediated afferent activity. J Neurosci 15:7037-7045.

Burgi PY, Grzywacz NM (1997) Possible roles of spontaneous waves and dendritic growth for retinal receptive field development. Neural Comput 9:533-553.

Catsicas M, Bonness V, Becker D, Mobbs P (1998) Spontaneous $\mathrm{Ca}^{2+}$ transients and their transmission in the developing chick retina. Curr Biol 8:283-286.

Cherubini E, Gaiarsa JL, Ben Ari Y (1991) GABA: an excitatory transmitter in early postnatal life. Trends Neurosci 14:515-519.

Constantine-Paton M, Cline HT, Debski E (1990) Patterned activity, synaptic convergence and the NMDA receptor in developing visual pathways. Annu Rev Neurosci 13:129-154.

Cramer KS, Sur M (1997) Blockade of afferent impulse activity disrupts on/off sublamination in the ferret lateral geniculate nucleus. Dev Brain Res 98:287-290.

D'Andrea P, Vittur F (1996) Gap junctions mediate intercellular calcium signalling in cultured articular chondrocytes. Cell Calcium 20:389-397.

Davidson JS, Baumgarten IM (1988) Glycyrrhetinic acid derivatives: a novel class of inhibitors of gap-junctional intercellular communication. Structure activity relationships. J Pharmacol Exp Ther 246:1104-1107.

Davidson JS, Baumgarten IM, Harley EH (1986) Reversible inhibition of intercellular junctional communication by glycyrrhetinic acid. Biochem Biophys Res Commun 134:29-36.

Ehrlich D, Keyser KT, Karten HJ (1987) Distribution of substance P-like immunoreactive retinal ganglion cells and their pattern of termination in the optic tectum of chicks (Gallus gallus). J Comp Neurol 266:220-233.

Feller MB, Wellis DP, Stellwagen D, Werblin FS, Shatz CJ (1996) Requirement for cholinergic synaptic transmission in the propagation of spontaneous retinal waves. Science 272:1182-1187.

Feller MB, Butts DA, Aaron HL, Rokhsar DS, Shatz CJ (1997) Dy- 
namic processes shape spatiotemporal properties of retinal waves. Neuron 19:293-306.

Fischer KF, Lukasiewicz PD, Wong ROL (1998) Age-dependent and cell class-specific modulation of retinal ganglion cell bursting activity by GABA. J Neurosci 18:3767-3778.

Frame MK, de Feijter AW (1997) Propagation of mechanically induced intercellular calcium waves via gap junctions and ATP receptors in rat liver epithelial cells. Exp Cell Res 230:197-207.

Galli L, Maffei L (1988) Spontaneous impulse activity of rat retinal ganglion cells in prenatal life. Science 242:90-91.

Goldberg GS, Moreno AP, Bechberger JF, Hearn SS, Shivers RR, MacPhee DJ, Zhang Y-C, Naus CCG (1996) Evidence that disruption of connexon particle arrangements in gap junction plaques is associated with inhibition of gap junctional communication by a glycyrrhetinic acid derivative. Exp Cell Res 222:48-53.

Hahm JO, Langdon RB, Sur M (1991) Disruption of retinogeniculate afferent segregation by antagonists to NMDA receptors. Nature 351:568-570.

Hamburger V, Hamilton HL (1951) A series of normal stages in the development of the chick embryo. J Morphol 88:49-92.

Hebb DO (1949) The organization of behavior. New York: Wiley.

Hughes WF, LaVelle A (1974) On the synaptogenic sequence in the chick retina. Anat Rec 179:297-302.

Hughes WF, McLoon S (1979) Ganglion cell death during normal retinal development in the chick: comparison with cell death induced by early target field destruction. Exp Neurol 66:587-601.

Inoue A, Sanes JR (1997) Lamina-specific connectivity in the brain: roles for $\mathrm{N}$-cadherin, neurotrophins, and glycoconjugates. Science 276:1428-1431.

Katz LC, Shatz CJ (1996) Synaptic activity and the construction of cortical circuits. Science 274:1133-1138.

Keyser KT, Hughes TE, Whitling PJ, Lindstrom JM, Karten HJ (1988) Cholinoceptive neurons in the retina of the chick: an immunohistochemical study of the nicotinic acetylcholine receptors. Vis Neurosci 1:349-366.

Kobayashi T (1993) Delay of ganglion cell death during retinal development in chick embryos. Neurosci Res 16:187-194.

Kobayashi T, Nakamura H, Yasuda M (1990) Disturbance of refinement of retinotectal projection in chick embryos by tetrodotoxin and grayanotoxin. Dev Brain Res 57:29-35.

Lippe WR (1994) Rhythmic spontaneous activity in the developing avian auditory system. J Neurosci 14:1486-1495.

Lipton SA, Aizenman E, Loring RH (1987) Neural nicotinic acetylcholine responses in solitary mammalian retinal ganglion cells. Pflügers Arch 410:37-43.

Meister M, Wong ROL, Baylor D, Shatz CJ (1991) Synchronous bursts of action potentials in ganglion cells of the developing mammalian retina. Science 252:939-943.

Mey J, Thanos S (1992) Development of the visual system of the chick-a review. J Hirnforsch 33:673-702.

Miller K (1996) Synaptic economies: competition and cooperation in synaptic plasticity. Neuron 17:371-374.

Mooney R, Penn AA, Gallego R, Shatz CJ (1996) Thalamic relay of spontaneous retinal activity prior to vision. Neuron 17:863-874.

Nakamura H, O'Leary DDM (1989) Inaccuracies in initial growth and arborization of chick retinotectal axons followed by course corrections and axon remodeling to develop topographic order. J Neurosci 9:3776-3795.

Nedergaard M, Cooper AJL, Goldman SA (1995) Gap junctions are required for the propagation of spreading depression. J Neurobiol 28:433-444.

O'Donovan MJ, Chun N (1997) Population behavior and selforganization in the genesis of spontaneous rhythmic activity by developing spinal networks. Semin Cell Dev Biol 8:21-28.

O'Leary DDM, Cowan M (1982) Further studies on the development of the isthmo-optic nucleus with special reference to the occurrence and fate of ectopic and ipsilaterally projecting neurons. J Comp Neurol 212:399-416.

O'Leary DDM, Cowan M (1984) Survival of isthmo-optic neurons after early removal of one eye. Dev Brain Res 12:293-310.

O'Leary DDM, Gerfen CR, Cowan M (1983) The development and restriction of the ipsilateral retinofugal projection in the chick. Dev Brain Res 10:93-109.

Penn AA, Riquelme PA, Feller MB, Shatz CJ (1998) Competition in retinogeniculate patterning driven by spontaneous activity. Science 279:2108-2112.

Pequignot Y, Clarke PGH (1992a) Changes in lamination and neuronal survival in the isthmo-optic nucleus following the intraocular injection of tetrodotoxin in chick embryos. J Comp Neurol 321:336-350.

Pequignot Y, Clarke PGH (1992b) Maintenance of targeting errors by isthmo-optic axons following the intraocular injection of tetrodotoxin in chick embryos. J Comp Neurol 321:351-356.

Rager G, Rager U (1976) Generation and degeneration of retinal ganglion cells in the chicken. Exp Brain Res 25:551-553.

Rager G, Rager U (1978) Systems matching by degeneration. I. A quantitative electron microscopic study of the generation and degeneration of retinal ganglion cells in the chicken. Exp Brain Res 33:65-73.

Ramon y Cajal S (1892) La retine des vertebres. La Cellule 9:119-257. Reprinted in: The vertebrate retina (Rodieck RW, ed), pp 775-904. San Francisco: Freeman, 1973.

Roskies A, Friedman GC, O’Leary DDM (1995) Mechanisms and molecules controlling the development of retinal maps. Perspect Dev Neurobiol 3:63-75.

Sernagor E, Grzywacz NM (1993) Cellular mechanisms underlying spontaneous correlated activity in the turtle embryonic retina. Invest Ophthalmol Vis Sci 34:1156.

Sernagor E, Grzywacz NM (1994) Synaptic connections involved in the spontaneous correlated bursts in the developing turtle retina. Invest Ophthalmol Vis Sci 35:2125.

Sernagor E, Grzywacz NM (1996) Influence of spontaneous activity and visual experience on developing retinal receptive fields. Curr Biol 6:1503-1508.

Sernagor E, O’Donovan MJ (1997) Cellular mechanisms underlying retinal waves in the chick embryo. Soc Neurosci Abstr 23:306.

Spitzer NC, Gu X (1997) Purposeful patterns of spontaneous calcium transients in embryonic spinal neurons. Semin Cell Dev Biol 8:13-19.

Stryker MP, Strickland SL (1984) Physiological segregation of ocular dominance columns depends on the pattern of afferent electrical activity. Invest Ophthalmol Vis Sci [Suppl] 25:278.

Weliky M, Katz LC (1997) Disruption of orientation tuning in the visual cortex by artificially correlated neuronal activity. Nature 386:680-685.

Wilshaw DJ, von der Malsburg C (1976) How patterned neural connections can be set up by self-organization. Proc R Soc Lond [Biol] 194:431-445.

Wong ROL (1997) Patterns of correlated spontaneous bursting activity in the developing mammalian retina. Semin Cell Dev Biol 8:5-12.

Wong ROL, Oakley DM (1996) Changing patterns of spontaneous bursting activity of On and Off retinal ganglion cells during development. Neuron 16:1087-1095.

Wong ROL, Meister M, Shatz CJ (1993) Transient period of correlated bursting activity during development of the mammalian retina. Neuron 11:923-938.

Wong ROL, Chernjavsky A, Smith SJ, Shatz CJ (1995) Early functional neural networks in the developing retina. Nature 374:716-718.

Wong WT, Sanes JR, Wong ROL (1997) Spontaneous activity patterns in the ganglion cell layer of the embryonic chick retina. Soc Neurosci Abstr 23:641.

Wu HH, Williams CV, McLoon SC (1994) Involvement of nitric oxide in the elimination of a transient retinotectal projection in development. Science 265:1593-1596.

Wu HH, Waid DK, McLoon SC (1996) Nitric oxide and the developmental remodeling of retinal connections in the brain. Prog Brain Res 108:273-286.

Yamagata M, Sanes JR (1995a) Lamina-specific cues guide outgrowth and arborization of retinal axons in the optic tectum. Development 121:189-200.

Yamagata M, Sanes JR (1995b) Target-independent diversification and target-specific projection of chemically defined retinal ganglion cell subsets. Development 121:3763-3776.

Yuste R, Peinado A, Katz LC (1992) Neuronal domains in the developing neocortex. Science 256:665-669. 